\title{
To the History of Studying of Evolution of the Russian Poetic Translation of the 19th Century
}

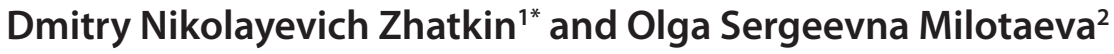 \\ 'Department of Translation and Methods of Translation, Penza State Technological \\ University, Penza, Russian Federation; ivb40@yandex.ru \\ ${ }^{2}$ Department of Foreign Languages of Penza State University of Architecture and \\ Construction, Penza, Russian Federation
}

\begin{abstract}
In the article systematization of data on the scientific works of the last decade devoted to studying of unfairly forgotten Russian translators' creative works of the 19th century, for example, E.I. Guber, N.V. Gerbel, D.E. Minh, D.L. Mikhalovsky, P.I. Veynberg, thanks to their activity many topmost achievements of the West European literature presented in Russian were for the first time carried out. Methodologically the research relies on fundamental works in the field of comparative and historical literary criticism, the Russian translated fiction, the Russian and West European literary and historical and cultural communications. In the article it is convincingly shown that in the history of the Russian translated literature of the 19th century there was a special hierarchy of literary names in which in the forefront in many respects there were authors who did not get popularity by their original creative works (in particular, N.V. Gerbel, D.L. Mikhalovsky) or not creating original works at all (D.E. Minh). The authors not only analyze the concrete translations executed in the second half of the 19th century but also prove the understanding of a role of this or that translator in promoting of works of the West European literature in Russia, note the most significant achievements, characterize the reasons of creative failures. Special attention is paid to prospects of studying of scientific problems, in particular, the need of emergence of the generalizing monographic and dissertation works about translation activity of D.D. Minayev, O.N. Chyumina, P.A. Kozlov, N.A. Holodkovsky, creation of the bibliographic editions containing data on publications of translated works in the Russian periodical press of the 19th century, preparation of anthologies of the chosen works of the leading Russian translators of that time is specified; the carried-out work will promote the creation of fundamental history of the Russian literary translation in future.
\end{abstract}

Keywords: Art Detail, Communications, Comparative Study, Cross-Cultural Communication, Literary Criticism, Poetic Translation, Poetry, Reception, Russian and West European Literary, Tradition

\section{Introduction}

Problems of the history of the Russian poetic translation involved the Russian literary critics both in the $19^{\text {th }}$ and in the $20^{\text {th }}$ century, however traditionally main attention was paid to sign events and translators from among the most considerable Russian writers (in particular, Homer's "Illiada" in N.I. Gnedich's translation, V.A. Zhukovsky, M.Yu. Lermontov, M.L. Mikhaylov, S.Ya. Marshak's translations, etc). At the same time many bright names of talented interpreters of the West European literature practically remained until the recent period of time in shadow, without causing true interest. In particular it concerns the second half of the $19^{\text {th }}$ century which was traditionally perceived as the period of decline in quality of literary translations against the sharp growth of quantity and therefore not drawing necessary research attention. Almost forgotten were names of the leading translators of that era D.E. Minh, D.L. Mikhalovsky, P.A. Kozlov, N.V. Gerbel, P.I. Veynberg, N.A. Holodkovsky whose activity promoted the development of the Russian and European literary and cultural dialogue, professionalizing of the Russian poetic translation, improvement of approaches and requirements to translation activity.

\footnotetext{
${ }^{*}$ Author for correspondence
} 


\section{Literature Review}

During a long period of time the only researcher who gave the survey characteristics of a creative heritage of the Russian translators of the $19^{\text {th }}$ century was Yu.D. Levin. Emergence in 1970-1990s of his works from which it is necessary to distinguish especially the books "Russian Translators of the $19^{\text {th }}$ century and Development of Literary Translation"1 and "The Perception of English literature in Russia"2, could give stimulus to thorough studying of the concrete translations, literary and critical materials of an era in the context of literary process, but it didn't occur. And only in recent years a number of considerable works was published, the dissertations devoted to deep studying of features of creative manners of the leading Russian translators who made the significant contribution to strengthening of international relations of the Russian literature were presented - N.V. Gerbel ${ }^{3}$, D.E. Minh ${ }^{4}$, D.L. Mikhalovsky ${ }^{5}$, P.I. Veynberg ${ }^{6}$. These early Russian studies are in essence innovative; only partly they could rely on achievements of foreign philological science ${ }^{7-11}$.

\section{Materials and Methods}

The researches of the Russian translation reception of English literature based on literary, literary and critical, memoirs and epistolary materials of the $19^{\text {th }}$ century became the material for consideration and judgment.

The theoretical and methodological base of the research is based on the works of classics of the Russian literary criticism A.N. Veselovsky ${ }^{12}$, V.M. Zhirmunsky ${ }^{13}$, M.M. Bakhtin ${ }^{14}$, the works of the researchers of international literary relations, first of all, of the representatives of the Leningrad comparative-historical school - M.P. Alekseev ${ }^{15}$, R.M. Gorokhova ${ }^{16}$, Yu. D. Levin ${ }^{1}$ K. I. Rovda ${ }^{17}$ and also on the works concerning problems of Russian-English and Russian-Italian literary and historical and cultural interaction. The results of work of bibliographers and originators of a reference media are considered (D.D. Yazykov, A.V. Mezyer, S.A. Vengerov, I.F. Masanov, N.P. Smirnov-Sokolsky, I.M. Levidova, V.T. Danchenko, etc.) thanks to which it was succeeded to keep and systematize the valuable factual material concerning separate publications of translators in the Russian periodical press of the second half of the $19^{\text {th }}$ the beginning of the $20^{\text {th }}$ century. In some cases the works of foreign scientists interesting in respect of judgment of Russian-foreign literary communications are attracted ${ }^{7-11}$.
In the course of the analysis the comparative and historical, comparative and typological, historical and genetic, social and cultural and biographic methods of research were used.

\section{Results}

Eduard Ivanovich Guber's (1814-1847) creative works, the Russian German by origin, the son of the Lutheran priest, were important for the development of Russian and German literary communications. Guber became famous for realization in 1838 of an ambitious plan of the first Russian translation of the tragedy of I.V. Goethe "Faust". The appeal of the Russian poet to the great work of the German literature was in many respects caused by influence of vital representations and civil belief of the German scientist-historian and writer I.A. Fessler (17561839) who lodged in Russia at the beginning of the $19^{\text {th }}$ century. Numerous responses of contemporaries testify to the importance of this translation for the subsequent development of the Russian culture. However translation activity of Guber is not much limited just by I.V. Goethe's tragedy. Guber also possesses the translations of four Goethe's poems - "Mankind borders", "Wanderer", "Let happiness stays with him...", "The Best in the world", and two last were united by the heading "Imitation to Goethe".

Creative activity of the Russian poet-translator, publisher, editor, bibliographer and literary critic Nikolay Vasilyevich Gerbel (1827-1883) was comprehended on the example of the translations of concrete works, in particular, of fragments of Christopher Marlo's play "Edward II", E. Spencer's "Epithalamium", P.B. Shelley's poem" An Ode to the Asserters of Liberty" in recent years. For example, it was noted that E. Spencer's work was full of numerous mythological images, for example, at the beginning of the fifth stanza "The Rosy Morne long since left Tithones bed, / <..> / And Phoebus gins to shew his glorious bed" [The dawn left a Pythia bed long ago, / <..> / And Feb rises to show his nice head] where also Pythia (pythoness) - the priestess-prophet were mentioned in Apollo's temple in Delphi, in Ancient Greece and Feb (Phoebus) - a name of Apollo as god of the Sun. In the early Russian translation presented by N.V. Gerbel, the tradition of the original was broken: Pythias were not mentioned at all, there was a characteristic of a dawn as "a queen" and at the description of Feb the outdated book and poetic lexeme "forehead" was used: "... Already the dawn-queen / Has woken up and goes ... / <..> / And Feb his forehead raises over the earth". 
N.V. Gerbel destroyed the verified structure of Spenser's work - if the stanza contained 18 -19 verses in the original, in translation the quantity of verses of a stanza varied from 12 to 20 and in general the fragment was reduced to 13 verses, apart from the admission of the eighth stanza. Having created in "Epithalamium" a peculiar monument to one day of his life, E. Spencer tried to give subjective nature of perception of the course of time by the groom, having discovered the principle of unevenness of art time. And though, unfortunately, the fragment translated by N.V. Gerbel does not reflect all this, however it has certain integrity, possesses some completeness. Defective display of rhythm and sound and art and graphic receptions of the author of "Epithalamium" in the Russian interpretation does not allow seeing E. Spencer's innovation in his experiments with loans from Safo and Katull, Dante and F. Petrarch, J. Chaucer and F. Sidney's creations. Nevertheless we should pay our attention to N.V. Gerbel as a translator because he was the first one to address to E. Spencer's creativity, difficult for understanding, the most difficult for interpretation "Epithalamium", to offer the Russian readers its original interpretation, during an era when theoretical bases of a literary translation weren't formulated.

Addressing to Shakespeare's sonnets, N.V. Gerbel considered them from the point of view of biographic approach. Now it is obvious that an identification of the lyrical hero of sonnets with Shakespeare is incorrect, because it after the entire poetic image having the same relation to the author as Othello or Hamlet. Of course, an image of the lyrical hero got much personal, for example some elements of theater life or some signs of addressees, but it is not a self-portrait, but an artistic image of the person, vitally truthful and real. In this biographic identification the reasons of why the sonnets in N.V. Gerbel's translation were irrelevant and unclaimed in next years are in many respects covered. At the same time N.V. Gerbel's translation of the entire ensemble of sonnets in very considerable measure stirred up interest in Shakespearean sonnets from the Russian poets and translators of the end of the $19^{\text {th }}$ century - whereas before N.V. Gerbel there was practically nothing, except alterations and several translations of I.A. Mamuna, after N.V. Gerbel the real surge in translation interest began.

N.V. Gerbel understood that art means of expression of Shakespearean sonnets are unusually rich: on the one hand, there is a lot of inherited from all European and English poetic tradition in them, on the other hand - much absolutely new in them. Poetic style of Shakespeare's sonnets means a word-play, abundance of epithets, comparisons and metaphors, the method of creation of an image consisting of use of lexicon of any subject, an antithesis and transfers of a sentence from line to line and from stanza to stanza (sometimes the whole sonnet consists of one - two sentences), a large number of alliterations, internal subrhyming, anaphors, repetitions, inversions and also the frequent deviations from the correct verse subordinated to a certain emotional pressure.

The loss of expressive epithets, the admission by N.V. Gerbel of a characteristic word-play, bring, in particular, to that the $16^{\text {th }}$ sonnet in its interpretation loses its expression, for example, instead of a poetic turn of "this bloody tyrant Time" there is an image of "gray-haired Time", instead of "my barren rhyme" it is mentioned "a bunch of my verses", instead of "... living flowers, / Much liker than your painted counterfeit" is called a bunch of flowers, "similar to you, as your portrait beautiful"18. If Shakespearean expressions quite often mean double reading ("lines of life" can be treated both as "live features" and as "lifelines" on which the fortune is told; "my pupil pen" can be translated both as "my inexperienced feather" and as "my feather directed by your beauty") and N.V. Gerbel being incapable to transfer the implication created by a word-play offers only one reading lying on a surface: "So should the lines of life that life repair, / Which this, Time's pencil, or my pupil pen, / Neither in inward worth nor outward fair, / Can make you live yourself in eyes of men"19 - "Yes, life has to represent itself, / As a feather and a brush can't order / To live eternally on a wall at guilty public/ Your image with the part neither internal, nor external"18. Along with obvious violation of management (it would be more correct "... to order $/<\ldots\rangle$ / your image ...") in N.V. Gerbel's translation the mentions of a feather and a brush meaning preservation of beauty in poetry and painting draw attention however the subsequent verse" to live eternally on a wall at guilty public " brings into bewilderment, why the feather is mentioned if only one way of imprinting of beauty - in the form of a picturesque portrait is meant. Obviously, under Gerbel's influence such reading remained also in translations of the subsequent time, for example, in B.V. Bair's ones.

In the $55^{\text {th }}$ sonnet the double sense extends on all text turned not only to the friend, but also to the poet that was quite clear to Russian literature as a poetic tradition to speak "you", addressing to itself, had existed in Russia since the romanticism era. In this case the double plan 
was especially necessary for Shakespeare because the sonnet represented a variation on the theme of Horace's ode of "Exegi monumentum" which caused subsequently emergence of works of M.V. Lomonosov ("I erected an immortality sign to myself ..., 1747), G.R. Derzhavin ("Monument", 1795), A.S. Pushkin "I erected a not handmade monument to me ..., 1836) in which by means of the address to itself the main ideological plan is transferred. Shakespeare intentionally maintains the double address in the sonnet, refusing from the use of pronouns "I", "my", etc.; N.V. Gerbel, not having seen this double reading again, used a pronoun "my" already in the second verse.

In spite of the fact that skill of sonnet creativity fully confirmed a high rank of the poet, it isn't necessary to take Shakespeare's text literally, to see in it self-confidence manifestations. N.V. Gerbel's use of such expressions as "the glorified verses" (instead of "powerful rhyme"), "a worthless plate" (instead of "unswept stone"), resulted in absolutely inappropriate sharpness of the description at a reconstruction of an image of the original poetry not subject to time: "Not marble, nor the gilded monuments/ Of princes, shall outlive this powerful rhyme; / But you shall shine more bright in these contents/Than unswept stone, besmear'd with sluttish time"19 - "To neither a proud pillar, nor a regal tomb / not to endure my glorified verses, / And your name will more reliably remain in them, / Than on a worthless plate, playing of centuries"18. We will note that in this case N.V. Gerbel's translation is not in the least better than modern for him I.A. Mamuna's translation also far from tragic lyrics of Shakespeare; it is especially noticeable by comparison of these two interpretations with the texts of better translations of the $55^{\text {th }}$ sonnet executed in the $20^{\text {th }}$ century by V.Ya. Bryusov and S.Ya. Marshak.

Of course, from positions of modern science it is possible to speak with confidence that the sense of not only these, but also some other sonnets was treated by N.V. Gerbel not absolutely truly. However for many other Russian interpreters of the $19^{\text {th }}$ century as, however and for the subsequent time, a word-play subtlety in Shakespearean sonnets were also not subjected.

A number of articles are devoted to the creative biography of the Russian poet-translator Dmitry Egorovich Minh (1818-1883). For example, in one of our works based on material of the comparative analysis of the translations of J.G. Byron's "Jewish melodies" made by D.E. Minh and by other interpreters it was noted that D.E. Minh's translations quite fit into a general series of art interpretations, approximately equivalent on the advantages, of J.G. Byron's texts made in the second half of the $19^{\text {th }}$ century. From three translations, perhaps, only the first - "Ah, cry as we cried on the rivers of Babylon..." - didn't lose the relevance, it continues to be reprinted in new editions of J.G. Byron's works. In this translation Minh's aspiration to subordinate his own talent to features of the translated author, truthfully, precisely and laconically reproduce the foreign-language text by means of Russian was distinctly shown. Other translations - "My soul is gloomy ..." and "Sennacherib's Defeat" - already at the time of their publication in 1906 had more historical and cultural, than esthetic value. However it must be noted that Minh carried out his interpretations much earlier, at the end of the 1850s when Byron's "melodies" were known only in translations of the Russian romantics of 1820-1830s.

The lifetime literary reputation of D.E. Minh consisted in his perception as a translator, professional, extremely exacting to himself who had profound knowledge of the Italian, English and German languages, being interested in poetic works of different eras, authors, genres and styles. Aspiration to preparation of the high-quality, academically verified translations in a combination of restraint of author's ambitions quite often led to the completion of already prepared texts was carried out by D.E. Minh for decades, their first publications appeared after death of the translator, having in many respects lost relevance in force as external (change of a public situation, literary tastes etc.) and internal (creation of other translations begun after D.E. Minh, but finished and published earlier and which in time occupied empty literary niche) reasons. This led to essential narrowing of perception of creativity of D.E. Minh who already by the beginning of the $20^{\text {th }}$ century was mainly characterized as the translator of one big work - Dante's "The Divine Comedy". Without being engaged in the original literary creativity, Minh saw the main objective in the fullest and exact reflection of specifics of foreign works in Russian. Such approach not corresponding to characteristic tendency of the translation development of 1850-1880s as a free interpretation, limited possibilities of Russian translation as the phenomena of domestic literature, but thus allocated it with the essential philological importance, fundamental validity that, finally, allowed Minh to take a unique place in the Russian literature and culture of the time.

Complexity of studying of Minh's creative works is in many respects caused by lack of the handiworks capable to give an idea of his translation principles. 
And still these principles, despite some "smoothness" of Minh's professional ambitions in the field of the translation, with all evidence appear and in texts of the translations and in author's comments to them and in responses of literary criticism; this preliminary studying of the foreign author and works of the Russian translators predecessors, observance of a verse form of the original, invariable improvement of language and style of the language, avoiding the ideological implication for the sake of objectivity at interpretation of a translated work. The advantage of Minh's translations is in harmonious translation of original author's plans in semantic, stylistic and pragmatical aspects. The translator seeking for the fullest reflection of foreign works in Russian managed to avoid frequent distortions towards literalism or a poetic license that left the original the fact of foreign literature, without turning it into the original work of the domestic author.

The choice of works for the translation was inevitably caused by D.E. Minh's ideological positions which were rather contradictory and didn't allow to correspond it directly both to a number of translators of "pure art" and to a number of their opponents from democratic literary circles. D.E. Minh, for many years holding high positions in Moscow University and having the solid social status, generally cooperated with the extremely right ideology of M.N. Katkov's "Russky Vestnik" (The Russian Messenger), but thus quite often addressed to interpretation of the works proclaiming ideas of social justice, need of education of a people at large etc. In this regard Minh's choice of J. Krabb's works is interesting, the priest, god-loving and law-abiding person who was capable unvarnished in his poems cruelty of the world, burden of country work, disgrace and injustice of the strong, their indifference to sufferings of people; also the personality of R.U. Buchanan translated by Minh is so contradictory combining loyalty of the power and internal rejection of public processes. D.E. Min for the first time in Russia addressed to the creative works of the English social democrat U. Morris, but chose for the translation the most neutral, deprived of revolutionary pathos work - the poem "Earthly Paradise", literary stylization created under the influence of the Pre-Raphaelite Dante Gabriel Rossetti and representing reality in an allegorical form.

In English poetry of the $16-18^{\text {th }}$ centuries D.E. Minh as a Russian poet-translator was attracted by only separate considerable names and that had in Russia the greatest popularity - J. Milton glorified by a set of translations of his "Paradise Lost", W. Shakespeare who got huge popularity with his plays from the middle of the $18^{\text {th }}$ century, R. Burns, whose original poetry was actively translated into Russian since the beginning of the $19^{\text {th }}$ century. The appeal of the Russian interpreter to the works of these poets had incidental character and was limited to single translations. The era of romanticism riveted the most considerable attention of D.E. Minh as a translator of English poetry. And the romanticism interested him in all its manifestations, this is a rebellious romanticism of J.G. Byron, T. Moore, P.B. Shelley's and pantheistical romanticism of the "lake school" poet W. Wordsworth and the romanticism painted by specific national Scottish color of the poet-painter of battle-pieces T. Campbell and late restoration romanticism of the poet of the Victorian era A. Tennyson. However at all variety of names the main interest of D.E. Minh was concentrated on creativity of J.G. Byron, distinguished with the scale, from J.G. Byron the most considerable Minh's translations from English were made (a vast fragment of "Don Juan", the poem "The Siege of Corinth", poems from the cycle "Jewish Melodies").

It is known that D.E. Minh worked on completion of the translations from Byron for decades, improving language and style, specifying concrete art details, understanding of separate images, nuances of the description. So, the translation published in 1880 "Don Juan on the island of the pirate" was a peculiar result of the work on fragmentary interpretation of the great Byron's poem begun in 1852. D.E. Minh managed not only to present a fragment of "Don Juan" as finished and self-sufficient work, but also to observe a poetic form of the original, to keep the unique author's irony, a rich figurative row, a difficult rhyme that in many respects that was not subjected to other Russian translators - to D.D. Minayev, P.A. Kozlov, G.A. Shengeli, T.G. Gnedich, using creative finds of D.E. Minh-interpreter.

Minh's translation of Byron's poem finished at the end of 1860 s and published in 1875 "The Siege of Corinth" favorably differed in completeness of a form, care of processing and depth of judgment of the original text that is especially visible in comparison with earlier fragmentary translation of I.I. Kozlov and less exact interpretation of N. V. Gerbel; due to this circumstance the translation remained demanded until the end of the 1930s. By the way, one of three Byron's "Jewish melodies" interpreted by D.E. Minh - "Ah, cry as we cried on the rivers Babylon ..." (published in 1859) - kept the relevance and until now 
it continues to be published in new editions of Byron's works. Two others "Jewish melodies" ("My soul is dark ...", "Sennakherib's Defeat") already at the time of their publication in 1906 had only historical and cultural value as, though fitted into a general series of approximately equivalent art interpretations of Byron's texts of the second half of the $19^{\text {th }}$ century executed by A.K. Tolstoy, D. D. Minayev, D. L. Mikhalovsky, P. A. Kozlov, N. V. Gerbel, etc. and in many respects the new requirements to a poetic translation which laid the foundation consisting in truthful and exact reproduction of a sense and a form of the foreign-language text by means of Russian nevertheless were printed after all others.

Dmitry Lavrentyevich Mikhalovsky (1828-1905) acting as the translator of the works of Shakespeare ("Julius Caesar", "Anthony and Cleopatra", "Richard II", "Henry V", etc.), J.G. Byron ("Mazepa", "Chayld-Harold's Pilgrimage", etc.), T. Goode, T.B. Macaulay, A. Tennyson, B. Kornuoll was one more remarkable personality in the Russian poetic translation of the second half of the $19^{\text {th }}$ century. Among the events of the last time - identification of the unknown translation of D. L. Mikhalovsky from Shakespeare: in the writer's fund in the Russian State Literature and Art Archive the unpublished translation of fragments of the first part of the historical chronicle "Henry IV" is found (ph. 309, op. 1, ch. 9). D.L. Mikhalovsky's operating time over a reconstruction of "Henry IV" authentically isn't established, however the remained multiple corrections and early editions of the translation allow to speak with confidence that the Shakespearean chronicle was difficult for the translator. In clean edition only the first scene of the first act of part I, two subsequent scenes remained in incomplete draft edition. D. L. Mikhalovsky often omits hints, significant for the English playwright, in particular, a mention of the heavens ("troubled heaven") foretelling a storm, the word-play of "opposed eyes" ("objecting eyes", "opposite eyes") meaning not only rebels in Wales, but also mistrustful citizens at court and Henry IV's illegitimacy urged to emphasize as governor, - instead of the last the expressional epithet "spiteful" at the characteristic of the opponent's eye is used: “... those opposed eyes, / Which, like the meteors of a troubled heaven, / All of one nature, of one substance bred, / Did lately meet in the intestine shock/And furious close of civil butchery ..." [these objecting eyes,/, Which, as if meteorites of the heavens foretelling a storm, / All of one nature, generated by one substance, / Which met in interstine fight] "Opponents spiteful eyes earlier, / Which as in the sky meteors, / Coming all from one nature, / From the general for all of them substances, - / Met here in interstine slaughters.... On unfinished work it is difficult to judge as far as D. L. Mikhalovsky's interpretation would be successful in comparison with readings of predecessors and contemporaries, however the found material helps to see creative laboratory of the translator. D.L. Mikhalovsky attentively worked with an art detail, seeking to inform to readers the smallest nuances of Shakespearean work, fully to discover intentions and desires of heroes of the historical chronicle.

P. I. Veynberg (1831-1908) was the figure which in many respects finished the whole stage of the history of the Russian literary translation. The translator addressed to the Scottish national ballad creativity, Elizabethan dramatic art (nine plays of Shakespeare), literature of the $18^{\text {th }}$ century (R. Sheridan, R. Burns), poetry and poetic dramatic art of English romanticism (J.G. Byron, P.B. Shelley's), to compositions modern to him authors (E. Barret Brauning, K. Rossetti, O. Wilde). In particular, the translation of R. Sheridan's "School of malignant gossip" made by P.I. Veynberg in many respects awakened attention to the work which wasn't translated in Russia since Catherine 2, but thus causing sporadic interest in respect of creation of imitations and processing "on the Russian way". However with all text and style accuracy testifying to high professionalism of Veynberg as a translator, his interpretation of "School of malignant gossip" nevertheless is executed with some share of negligence. In a compilation biographic sketch about Sheridan written with a support on known A.V. Druzhinin's research "Life and drama works of Richard Sheridan" (1854) P. I. Veynberg distinctly accented the mind and Sheridan's wit and also that circumstance noted by Byron that Sheridan, according to Byron's point of view, created the best comedy ("School of malignant gossip"), the best opera ("Duenya"), the best farce ("Critic"), the best panegyric ("On the death of Garrick"); P.I. Veynberg's opinion on Sheridan was not so enthusiastic, moreover, he and Byron's words urged "to accept with restriction" as caused "and personal friendship of the well-known poet with Sheridan, and $\langle\ldots\rangle$ by fresh impression of the death of this last"20.

Creating new translations of works of the English authors who were traditionally popular in Russia - W. Shakespeare and J.-G. Byron, P.I. Veynberg achieved success with variable result. His translation of Shakespeare's "Othello" separate phrases from which 
even passed into a number of "winged" became an undoubted achievement of the translator ("she loved me for torments and I loved her for compassion to them", "a monster with green eyes"). This translation characterized by availability to perception, omission of insignificant details of the description, versification professionalism, skill in a reconstruction of the developed remarks was repeatedly quoted in the works of Russian writers, literary critics and literary critics of the second half of the $19^{\text {th }}$ - the beginnings of the $20^{\text {th }}$ century, repeatedly republished and in 1919 was cardinally processed by A. A. Blok for a performance in Bolshoi Drama Theater in St. Petersburg. The other P. I. Veynberg's translations from W. Shakespeare were less successful, however (in considerable part) continued to be republished because of P. I. Veynberg's high literary reputation as a translator of the West European literature and lack of new highquality translations; some of them, against the general complaints about obsolescence and imperfection, could keep on a scene and in the press till 1930s ("The Venetian merchant", "Windsor prankishes", "How it will be pleasant to you", "The comedy of mistakes").

Among P. I. Veynberg's translations from J.- G. Byron it can't be marked out undoubted artistic triumphs, however that circumstance is represented essential that many from Byron's works in 1870s were for the first time translated by P.I. Veynberg into Russian; in this regard, in particular, it is necessary to mention a prose translation of satire "English bards and the Scottish observers", the translations of a mystery fragments "Sky and Earth" and a poem "Dante's Prophecy", considerable on volume (from the last before the publication of P. I. Veynberg's translation in Russian only the small fragment translated by K. B. Kartamyshev was known). First also Veynberg's translation of J.- G. Byron's tragedy "Sardanapal" was fragmentary limited with acts 1-4 and added with the fifth act only at the beginning of the $20^{\text {th }}$ century when the interest to a subject in essential degree was weakened and the translation lost its innovative value. J.-G. Byron's poetry translations, undertaken by P.I. Veynberg in the period of early works (1850s -1860s), either didn't sustain a comparison with the translations of poets- predecessors ("Darkness" was more successfully translated by I. S. Turgenev, "Oskar D’Alvah" - by A.I. Polezhayev) or for certain time occupied a niche in reader's consciousness, but gradually were forced out from it ("Dream").

\section{Discussion}

In recent years the articles devoted to the activity of some other poets-translators of the $19^{\text {th }}$ century, in particular, "the blind singer" I.I. Kozlov, whose "The evening ring" (the translation from Thomas Moore) became the song, popular in the people, were issued. Materials in which the emphasis of researchers is focused not on translation and on literary and critical literary reception are also published. The special group of articles is devoted to perception by the Russian writers of separate images which sources it is possible to see in foreign literature (since antiquity). Perhaps, the most debatable still remain a question: what in a modern situation should pay prior attention? Undoubtedly, articles devoted to evolution of interpretations of separate motives and images are submitted the most essential in respect of specification and development of representations in the field of historical poetics. However it is necessary for their writing accumulation of extensive factual material and its systematization precede; in this regard a prior preparation of detailed reviews of activity of the most considerable translators which have to be followed by the valuable bibliographic device is represented to us.

The conducted research serves as evident argument against traditional perception of Russian translation 1860-1870s as the process of representatives fight of two ideological camps - noble and liberal (A.V. Druzhinin, A.K. Tolstoy, etc.) and revolutionary and democratic (M.L. Mikhaylov, D.D. Minayev, etc.). This process, indisputably, is important; however considerable part of the Russian translators, separating from it, without adjoining directly one of the camps, achieved significant results first of all thanks to ability to feel subtly characteristics of the interpreted originals, to refuse from introduction into them of their own thoughts and ideas to please to actual tendencies of public life.

\section{Conclusions}

Noting that in recent years it is made a lot for judgment of activity of talented translators E.I. Guber, N.V. Gerbel, D.E. Minh, D.L. Mikhalovsky, P.I. Veynberg who made glory of the Russian translated fiction of the $19^{\text {th }}$ century at the same time it is necessary to recognize that the considerable volume of laborious work is necessary: 
separate monographic researches are deserved by the translation activity of D.D. Minayev, O.N. Chyumina, P.A. Kozlov, N.A. Holodkovsky.

Also deeper studying of publishing activity in Russia of the second half of the $19^{\text {th }}$ century in aspect of promoting of works of the West European writers is obviously necessary. In this regard the thorough analysis of publishing priorities and preferences of N.H. Katcher, I.P. Bocharov, K.I. Timkovsky, A.A. Krayevsky, N.V. Gerbel, P.I. Veynberg, A.E. Gruzinsky that in many respects formed tastes of domestic public would be interesting, promoted development of cross-cultural communications, theoretical fundamentals of theory of translation and also improvement of translation practice.

Preparation and release of the bibliographic editions generalizing data on publications of translated works in the Russian periodical press of the $19^{\text {th }}$ century, creation of anthologies of the chosen works of the leading Russian translators of that time have to become an important stage of work. In this regard the half-forgotten bibliographic works of N.V. Gerbel devoted to I.P. Kreshev, D.L. Mikhalovsky, N.V. Berg and other Russian poets-translators who can be used at creation of factual bases of future researches of works of these translators in aspect of Russian-foreign literary and historical and cultural interaction are especially valuable promote consideration of scientific problems both with literary and from the esthetic, philosophical, historical, linguistic points of view.

Finally all these materials can form the basis of future academic history of the Russian translated fiction of the $19^{\text {th }}$ century which creation represents the special importance for modern philological science.

\section{Acknowledgement}

This research was executed with the financial support from the Ministry of Education and Science of the Russian Federation. A unique identifier of the applied research is MD-5818.2015.6 "Textual criticism and poetics of Russian art translation of $19^{\text {th }}$ - the early $21^{\text {st }}$ century: reception of English poetry of the Victorian Age in synchronism and diachronic".

\section{References}

1. Levin Y D. Russian translators of the 19th century and the development of art translation. Leningrad: Science; 1985.

2. Levin Y D. the perception of english literature in Russia: Investigations and materials. Nottingham: Astra Press. 12; 1994.
3. Teng-Chagay N Yu. Creative and publishing of N.V. Gerbel in the context of Russian-English literary communications of the 19th century. [PhD Thesis in Philology]. Saratov: Saratov State University named after N. G. Chernyshevsky; 2011.

4. Milotayeva O C. D.E. Minh's creative works in the context of Russian-English literary and historical and cultural communications of the 19th century. [PhD Thesis in Philology]. Saratov: Saratov State University named after N.G. Chernyshevsky; 2012.

5. Krekhtunova EV. D.L. Mikhalovsky's creativity in the context of Russian-English literary communications of the 19th century. [PhD Thesis in Philology]. Saratov: Saratov State University named after N.G. Chernyshevsky; 2013.

6. Kornaukhova TV. P.I. Veynberg's creativity in the context of Russian-English literary communications of the 19th - the beginning of the 20th century. [PhD Thesis in Philology]. Saratov: Saratov State University named after N. G. Chernyshevsky; 2014.

7. Engel-Braunschmidt A. Deutsche Dichter in Russland im 19. Jahrhundert: N. V. Gerbel's "Deutsche Dichter in Biographien und Proben» als Zentrum der Kenntnis und Verbreitung deutscher Dichtung. Munchen: W. Fink; 1973.

8. Waddington P. Turgenev's relations with Henry Fothergill Chorley (with an unpublished letter). New Zealand Slavonic Journal, 1978; 2:27-39.

9. Waddington P. Turgenev and England. L. - Basingstoke: Macmillan. 10; 1980.

10. Waddington P. Tennyson and Russia. Lincoln: Tennyson Research Centre; 1987.

11. Cross A. By the banks of the Neva: Chapters from the lives and careers the British in Eighteenth-Century Russia. Cambridge: Cambridge University Press. 15; 1997.

12. Veselovsky AN. The western influence in new Russian literature. Moscow: (Russkoye tovarischestvo pechatnogo i izdatelskogo dela); 1896.

13. Zhirmunsky B M. Verse and translation. In Russian-European literary communications (pp. 423-470). Leningrad: Nauka; 1966.

14. Bakhtin MM. Questions of literature and esthetics. Studies of different years. Moscow: Hudozhestvennaya literature; 1975.

15. Alekseev MP. Problem of literary translation. Collection of works of Irkutsk state university. Vol. 18. Ed. 1 (p. 149-96). Irkutsk: Irkutsk State University Press; 1931.

16. Gorokhova PM. Dante's "Hell" in D. E. Minh's translation and imperial censorship. In Russian and European literary communications: The collection of articles for the 70th anniversary since the birth of the academician M. P. Alekseev (p. 48-55). Moscow-Leningrad: Nauka. 1966.

17. Rovda KI. Years of reaction. In Shakespeare and Russian culture (p. 627-98). Moscow-Leningrad: Nauka; 1965.

18. Gerbel N V. Complete collection of poems: In 2 vols. St. Petersburg: V. Bezobrazov's printing house; 1882.

19. Shakespeare W. Sonnets. Moscow: Monolit; 2005.

20. Veynberg P I. Richard-Brinsli Sheridan (Biographic sketch). In R. B. Sheridan. School of Malignant Gossip: Comedy. P.I. Veynberg's translation (pages 157-69). St. Petersburg: A.E. Landau's tipolitografiya; 1875. 